How to cite this article:

Lee, A.X., \& Hooy, C.W. (2020). State ownership and risk-taking behaviour: Evidence from Malaysia's banking industry. International Journal of Banking and Finance, 15(2), 65-94. https://doi.org/10.32890/ijbf2020.15.2.4

\title{
State Ownership and Risk-Taking Behaviour: Evidence from Malaysia's Banking Industry
}

${ }^{1} \mathrm{Ai}$-Xin Lee

${ }^{2}$ Chee-Wooi Hooy

School of Management,

Universiti Sains Malaysia, Malaysia

1aixinlee@student.usm.my;

${ }^{2}$ Corresponding author: cwhooy@usm.my

A R T I C L E I N F O

Article history:

Received 30 March 2020

Revised 10 June 2020

Accepted 19 June 2020

Published 31 July 2020

JEL Code: G21, G28, G32, G34

Keywords:

State ownership, GLICs, risk-taking, corporate governance, board of directors, Malaysia.
A B S T R A C T

This study investigates state ownership on risk-taking behaviour in Malaysia's banking industry. Using the panel of Malaysian commercial banks, this paper examines whether banks' risk-taking is affected by Malaysian government ownership through the five largest investment arms of Malaysia (GLICs). The findings show that state-owned banks exhibit higher risk-taking behaviour compared to the private-owned banks in terms of loans. There is evidence that a higher degree of state ownership has a more significant impact on banks' risk-taking behaviour. We also investigate the relationship with corporate governance mechanisms. The findings suggest that the composition of board of directors somehow plays a significant role in the governance of banks. 


\section{Introduction}

The banking sector plays a significant role in Southeast Asia's economic development for the past 40 years. An effective and secure financial system in the banking sector has attributed to an outstanding high record on East Asia economic growth in the mid-90s (World Bank, 1993). However, the Asian banking industry has undergone extensive financial transformation where many banks were forced to consolidate after an overwhelming impact during the previous financial crises. As a result, the number of commercial banks operating in Malaysia has reduced to 26.

One common characteristic of previous financial crises incident is that banks have taken excessive risks and ended up with too many defaults. Governmental bailouts have also been blamed for creating incentives for banks to undertake excessive risks that contributed to these financial crises. Global Financial Development Report (2019/2020) claimed that there was extensive government intervention in backing up the national banking systems at that time. There is also no exception in Malaysia, where the Malaysian government has bailed out well-connected ailing, debt-ridden enterprises through GovernmentLinked Investment Companies (GLICs) and Government-Linked Companies (GLCs) (Gomez, Padmanabhan, Kamaruddin, Bhalla \& Fisal, 2018). The act of government intervention to rescue financial institutions has direct and indirect economic costs that have long-lasting effects (Global Financial Development Report, 2019/2020). The government intervention is further concerned when its involvement in the banking sector has intensified after the financial crises, particularly Asian countries that have greater government ownership involvement compared to other regions (Hossain, Jain \& Mitra, 2013). Prior studies claimed that the presence of moral hazard behaviour induced by government explicit and implicit protection leads to excessive risk-taking behaviour since it does not have to bear the costs (Jensen \& Meckling, 1976; Global Financial Development Report, 2019/2020; Zhu \& Yang, 2016). Excessive risk-taking behaviour in the banking industry could mark the onset of a banking crisis. Severe consequences on excessive risk-taking can be seen in the incident of Lehman Brothers bankruptcy during the Subprime crisis. They had taken excessive risks in creating loans, hence could not pay the excessive debts and faced unprecedented losses.

In light of globalisation in the banking sector, the central bank of Malaysia (Bank Negara Malaysia) has taken the initiatives to strengthen Malaysia's economies and boost the role of banking sector as a key element of national economic growth to compete in a more liberalised and challenging environment. Chin (2015) claimed that protracted affirmative action policies have led to the protectionism of local banks in Malaysia that favoured state-owned banks. The policies enforced by the government after the recent Global financial crisis has produced power shift which driven Malaysia's state-owned banks to seize 
more opportunities where foreign banks were impotent and have to withdraw their business in Malaysia. This reveals that the state authority is strong in the Malaysian banking sector. In view of liberalisation in the banking sector, the risk exposure faced by banks nowadays has become greater with the expansion of the banks' business scope and economic activities. This is predominantly important for commercial banks in Malaysia since they are the largest and most significant providers of funds in the Malaysian banking system. About 55.61 percent of the total loans in the banking system are derived from the household sector including mortgages, personal loans and hire purchase loans ${ }^{1}$. Currently, there are 26 commercial banks of which eight of them are local commercial banks. These commercial banks were governed by the Banking Act 1973 and Finance Companies Act 1969 under a single legislation.

As indicated in the earlier paragraph on the Malaysian government bailout during previous financial crises, GLICs, indeed, play a significant part in the nation's economic development. A key characteristic of Malaysia's economy under GLIC-led framework is that government has substantial influence in intervening the economy through their ownership in business operations due to their political, social and economic interests (Gomez et al., 2018; Shleifer \& Vishny, 1994) and these GLICs are closely tied with government policies (Abdul Razak, 2011). Following Haggarty and Shirley (1997) and OECD (2013), GLICs are defined as government-owned or -controlled investment companies that have a primary commercial objective. The Malaysian government has a direct controlling stake on the management decisions by virtue of its share ownership through GLCs or GLICs, that is, the ability to appoint senior management or make major decisions such as contract awards, strategy, restructuring, and financing, acquisitions and divestments. These GLICs constitute a significant part of the Malaysian economic structure as they hold more than 50 percent of the whole market capitalisation and majority ownership of Malaysia's leading public listed firms. According to Gomez et al. (2018), GLICs hold majority ownership of 35 public listed firms from Malaysia's Top 100 companies. This study focuses on five major GLICs that hold majority ownership in local commercial banks. They are known as Employees Provident Fund (EPF), Permodalan Nasional Berhad (PNB), Khazanah Nasional Berhad (KNB), Lembaga Tabung Angkatan Tentera (LTAT) and Lembaga Tabung Haji (LTH). Statistics show that EPF owns 45.34 percent of RHB Bank Berhad, PNB owns 42.96 percent shares in Malayan Banking Berhad, KNB owns 29.71 percent shares in CIMB Bank Berhad whereas LTAT has contributed to 35.42 percent of ownership in Affin Bank Berhad ${ }^{2}$.

The existing literature on GLICs or state ownership were mainly focused on firm performance (see Abdul Razak, Ahmad \& Aliahmed, 2008; Abdul Rahman \& Rejab, 2013; Hamid, 2011; Najid \& Rahman, 2011; Taufil-Mohd, Md-Rus \& Musallam, 2013). Similarly, other studies conducted in the developed countries also shared such findings (see Berger, Clarke, Cull, Klapper \& Udell, 
2005; Cornett, Guo, Khaksari \& Tehranian, 2010; Iannotta, Nocera \& Sironi, 2007). However, the literature on the relationship between state ownership and risk-taking is scarce. Risk-taking is one important dimension for corporate success and it has an impact on national economic development, particularly the banking sector where the risk undertaking of a bank not only has an enormous impact on banks' profitability but the national economy as a whole. In the event of excessive risk-taking, the impact of bank failure can spread to other banks and perhaps hitting the entire nation as well as the global economy (Stiglitz, 1993). Understanding the peril of excessive risk-taking, only a small number of recent studies examined the impact of state ownership on risk-taking. Notably, most of the extant studies were conducted in Western countries and developed countries such as Argentina, European countries, Middle East and North Africa (MENA) countries and the United States (see Brandao-Marques, Correa \& Sapriza, 2020; Iannotta, Nocera \& Sironi, 2013; Lassoued, Sassi \& Ben Rejeb Attia, 2016; Uddin, 2016). The studies have also evolved into Asian countries lately (see Lee \& Hooy, 2020; Vo, 2018; Zhu \& Yang, 2016). Although there have been increasing empirical studies conducted in Western countries and developed countries, very little attention has been given to emerging market such as Malaysia in examining the impact of state ownership on the banks' risktaking. It is relatively important to explore this issue in Malaysia where GLICs hold majority ownership in local commercial banks.

Prior study claimed that banks have a greater propensity to undertake risky projects if they have a direct link with the government (Lassoued et al., 2016). This statement is further supported by the empirical findings where state ownership is found positively related to risk-taking (Brandao-Marques et al., 2020; Iannotta et al., 2013; Lassoued et al., 2016; Zhu \& Yang, 2016). The existing literature also proves that state-owned banks (SOBs) tend to have poorer performance, are less efficient and less profitable and incur greater credit risks compared to private-owned banks (POBs). They claimed that these differences between SOBs and POBs are more eminent in countries that had greater government involvement in the banking system, particularly in Southeast Asia where SOBs are found underperforming (Cornett et al., 2010; Naima, Houda \& Mouna, 2016). On the contrary, some other studies found a negative relationship between state ownership and risk-taking (see Vo, 2018) and the nonlinear relationship (see Uddin, 2016).

The flaw in the functioning of corporate governance (CG) mechanisms has also played part of the root in previous financial crises that indirectly encourage government intervention in the banking sector. Gomez et al. (2018) argued that there is no effective body in Malaysia that can monitor the governance and performance of state-owned enterprises (SOEs) although there is a wellstructured governance mechanism in many other countries' SOEs. Hence, having a sound $\mathrm{CG}$ mechanism in the Malaysian banking system is crucial in 
monitoring bank activities and investment decisions. Liang, $\mathrm{Xu}$ and Jiraporn (2013) and OECD (2006) claimed that the board of directors play an important role in establishing a sound bank governance. The finding from prior studies provides evidence that firms with more effective governance are associated with a lower level of risk-taking, particularly board of directors who play the effective monitoring role in reducing excessive risk-taking behaviour (Anderson, Mansi \& Reeb, 2004; Jiraporn, Chatjuthamard, Tong \& Kim, 2015; OECD, 2006). Hence, the fiduciary duty carried out by the board of directors is deemed important in the banking sector than any other industry since any shortcomings of bank governance could lead to potential financial system failure. Prior studies have highlighted the fact that banks tend to undertake excessive risk when there is state ownership in the bank. However, the existing studies do not examine CG mechanisms in moderating the impact of state ownership on the banks' risktaking. Hence, this further motivates the exploration of CG mechanisms in this study.

This study adds value to the existing literature in twofold. Firstly, this study contributes by being a pioneer study addressing state ownership through GLICs and their risk-taking behaviour in Malaysia's banking industry. Malaysia, being one of the Southeast Asian countries, is the best teaching material for this research study. In addition, the Malaysian commercial bank is the largest and most significant provider of funds in the Malaysian banking system, the level of banks' risk-taking could give a large impact on nation economic development. Secondly, most of the existing literature has largely ignored the role of corporate governance mechanisms while examining this relationship. Using Malaysia data, we look at how banks' risk-taking behaviour is affected by the corporate governance mechanisms through different compositions of the board of directors such as board independence, foreign director and female director. The results of this study are important in providing insights into the role of government intervention and bank decision making through their understanding of the relationship between state ownership and risk-taking behaviour. We find that the role of state ownership is significant in determining the banks' risk-taking behaviour in Malaysia. We also find that the composition of board of directors somehow plays a significant role in bank governance.

This paper proceeds as follows. Hypotheses development is discussed in Section 2. Data, variables and summary statistics are presented in Section 3. Then, the results of data analysis are shared in Section 4 and the paper ends with the conclusion and implications in the last section (Section 5).

\section{Hypotheses Development}

Three theories have been widely used in the study of the relationship between state ownership and risk-taking behaviour. Firstly, the moral hazard theory. The 
action of financial bailouts by institutions, i.e., the government, would encourage riskier behaviour in the future if those risk-taking parties believe that they are not going to be responsible for the consequences as a result of excessive risk-taking behaviour (Krugman, 2009). Besides, the "too big to fail" perspective also leads to moral hazard as they believe that the government would not be willing to let larger banks fail and hence, is more likely to bail them out. Secondly, the agency theory. This theory focuses on the conflict of interest arises between the major and minor shareholders. Shareholders who have dominating power have the incentives to affect the banks' decisions by undertaking riskier investments (Laeven \& Levine, 2009; Shleifer \& Vishny, 1986). Thirdly, the social lending theory. This theory shows the need of the government to accomplish social objectives. Prior studies claimed that SOBs tend to channel resources for socially beneficial projects that aim to increase job creations and developing nations where the social returns fail to be taken into account by the POBs (Berger et al., 2005; Stiglitz, 1993).

In addition to the above theories, prior studies showed that state ownership encourages banks to take more risks. This is further supported by empirical findings where state ownership is positively associated with risk-taking. This leads SOBs to hold less core capital, less profitability and incur greater credit risk than POBs (Brandao-Marques et al., 2020; Iannotta et al., 2013; Lassoued et al., 2016; Zhu \& Yang, 2016). These findings are consistent with the agency theory where banks controlled by major shareholders are found to have a tendency to undertake more risk. Since GLICs hold majority ownership in local commercial banks where the Malaysian government has a direct controlling stake, this study examines whether the state ownership and SOBs are associated with higher risktaking. Three risk-taking measurements are employed in this study; the credit risk proxy by non-performing loans (NPL) ratio, the capital adequacy proxy by capital adequacy ratio (CAR) and the liquidity risk proxy by liquidity ratio (LR). Koudstaal and Wijnbergen (2012) reported that the more troubled the loan portfolio, the greater the inclination for banks to take risks. A larger number of NPLs due to excessive risk-taking in lending could be used to mark the onset of a banking crisis (Reinhart \& Rogoff, 2011; Jensen \& Meckling, 1976). Moreover, capital adequacy plays an important role for banks solvency and their protection from untoward events which arise as a result of liquidity risk as well as the credit risk that banks are exposed to in the normal course of their business (Karim, Hassan, Hassan \& Mohamad, 2014; Athanasoglou, Brissimis \& Delis, 2008). Insufficient equity capital has also been partly blamed in the Global financial crisis and the Asian financial crisis. Moving on, LR could be used to measure a bank's financial health and it presents a preliminary expectation regarding the solvency of a company (Imbierowicz \& Rauch, 2014). A study from De Haan and Van Den End (2013) suggested that the extended liquidity support by the central bank might have been an incentive for banks to reduce their liquidity 
buffers. The subprime crisis that happened in 2008 has demonstrated how severely illiquidity can crystallise. To conclude, these three proxies are important in determining the banks' risk-taking behaviour and therefore, are employed in this study. Based on the theoretical perspectives and empirical finding from prior studies, we proposed our first hypothesis as follows:

$\mathrm{H}_{1 \mathrm{a}}$ : State-owned banks have higher risks than private-owned banks.

$\mathrm{H}_{1 \mathrm{~b}}$ : The degree of ownership by Malaysian government in banks significantly increases banks' risk-taking behaviour.

The flaw in the functioning of CG mechanisms has played part of the root in previous financial crises where there are massive government intervention and excessive risk-taking behaviour in the banking sector. Shareholder-friendly $\mathrm{CG}$ is also found connected with higher risk-taking (Anginer, Demirguc-Kunt, Huizinga \& Ma, 2018). As indicated by Gomez (2005), the issue of ownership and the act of controlling a bank or enterprise is a key issue in the most definition of CG. This issue is even more crucial in developing countries such as Malaysia where the government has a dominant controlling stake and decision making in the national economy. Hence, it is important to establish sound CG in the Malaysian banking sector to ensure that the investment decisions or strategies made by banks are well-monitored to prevent excessive risk-taking behaviour. A good CG comes from the essential role and the fiduciary duty play by the board of directors (Gomez, 2005). Prior studies also showed that sound bank governance played by the role of the board of directors is relatively important in the banking sector as the effective monitoring roles by the board is connected with lower risk-taking (Anderson et al., 2004; Jiraporn et al., 2015; Liang et al., 2013; OECD, 2006). Thus, this study focuses on three CG mechanisms (board independence, foreign director, and female director) in moderating the impact of state ownership through GLICs on banks' risk-taking.

The earlier literature studies on corporate governance issues provide no definite findings on the role of independent directors. Advocates show that organisations will become more effective and efficient in reducing agency issues and moral hazard with the presence of independent directors on board (Rosenstein \& Wyatt, 1990; Klein, 2002; Nguyen \& Nielsen, 2010). However, another strand of literature argues that independent directors may lack sufficient knowledge of the firm-specific information and lead to sub-optimal decisions (Raheja, 2005). In the case of state ownership, OECD (2006) suggested that an adequate number of independent directors on the board of SOBs be included. This is to ensure that the decision made by the board is independent and does not interfere by the government. Based on the previous studies, we developed the second hypothesis as follows: 
$\mathrm{H}_{2}$ : Board independence significantly affects the impact of ownership by Malaysian government on banks' risk-taking behaviour.

Foreign directors are non-local directors who served on the board. The role of foreign director is ambiguous although many researchers have examined this in their studies for the past few decades. Statement shows that foreign directors bring new technology and managerial expertise which brings better supervision by reducing information asymmetry and agency cost (Ezat \& ElMasry, 2008; Samaha, Dahawy, Hussainey \& Stapleton, 2012). Berger, Hasan and Zhou (2009) asserted that minority foreign ownership takes positions on the board and "leverage" the positions to monitor and improve bank management. Others contend that foreign directors are likely to be less familiar with national accounting standard and management methods, making it more difficult for foreign directors to appraise managerial performance or challenge managerial decisions. Based on these vague statements, we examine the effect of foreign director in the Malaysian banking industry with the third hypothesis developed as follows:

$\mathrm{H}_{3}$ : Foreign director significantly affects the impact of ownership by Malaysian government on banks' risk-taking behaviour.

Recently, female directors have become the theme of corporate governance mechanisms that arouse wide concern in research worldwide. Adams and Ferreira (2009) found that female directors are more likely to join monitoring committees and improve firm performance by easing the weak governance in Chinese listed firms. For example, corporate governance could be strengthened through improved monitoring and greater oversight of management by female directors. However, some other literature suggests that female directors in statecontrolled firms are required to divert part of their efforts to non-profit related political and social activities. In other words, female directors in state-controlled firms are more likely charged with social or political tasks. Hence, it is vital for us to examine the role of female directors. The fourth hypothesis is developed as follows:

$\mathrm{H}_{4}$ : Female director significantly affects the impact of ownership by Malaysian government on banks' risk-taking behaviour.

\section{Research Methodology}

\subsection{Sample Banks}

We first identified and obtained the list of banks involved in this study from Bank Negara Malaysia (BNM). We construct a balanced panel of 8 public listed 
local commercial banks in Malaysia from year 2011 to 2015. Foreign-owned commercial banks are excluded in the sample due to data limitations. Besides, the five major GLICs hold more than 50 percent of the whole market capitalisation and they have hold majority ownership in the local commercial banks. Hence, our final sample of this study focuses on local commercial banks. By referring to annual reports released from the Bursa Malaysia website, relevant data such as government shares ownership, bank's liquidity and profitability, bank's level of risk, bank's size, and bank's revenue growth could be identified. Hence, all the data employed in this study are hand collected.

We have state-owned banks and private-owned banks in our sample. We define banks as state-owned banks if: (1) Malaysian government owns the largest percentage of ownership through five major GLICs, namely EPF, PNB, KNB, LTAT and LTH; (2) The degree of government ownership is equal to or more than 40 percent. Likewise, for the private-owned bank, it is defined as such if the private entity owns the largest percentage of ownership in the bank.

\subsection{Variables Measurement}

\subsubsection{Measures of state ownership}

State ownership is the independent variable that will give an impact on the banks' risk-taking behaviour. In this study, we focus on Malaysian government ownership through the five largest GLICs in Malaysia. They are Employees Provident Fund (EPF), Permodalan Nasional Bnd(PNB), Khazanah Nasional Bhd (KNB), Lembaga Tabung Angkatan Tentera (LTAT) and Lembaga Tabung Haji (LTH). These investment institutions have also hold majority ownership in the local commercial banks. Hence, we employ two state ownership measurements in this study. They are dummy of state ownership (dummySO) and degree of state ownership (SO). Dummy of state ownership takes a value of " 1 " if (1) Malaysian government owns the largest percentage of ownership; (2) the total of ownership is more than or equal to 40 percent or " 0 " otherwise. Besides, the degree of ownership by Malaysian government is obtained by taking the percentage of shares held by these five investment institutions in the banks.

\subsubsection{Measures of risk-taking}

In this study, we would like to know the impact of the degree of ownership by Malaysian government through GLICs in local Malaysian commercial banks on their risk-taking behaviour. With carefully selecting the dependent variables of this study, we have come to three measurements of risk-taking employed in this study. They are non-performing loans (NPL) ratio, capital adequacy ratio (CAR) and liquidity ratio (LR). 
Since decades ago, the NPL ratio has been widely used by researchers to study the factors behind and risk associated with this ratio. For instance, it has been used by Jensen and Meckling (1976), Demirguc-Kunt (1989), Barr, Seiford and Siems (1994), and Koudstaal and Wijnbergen (2012). We expect banks with a greater percentage of Malaysian government ownership would have a higher NPL ratio as a result of a more risk-taking of a bank. NPL ratio can be calculated by using the formula as shown below:

$$
\text { Non }- \text { Performing Loans }(N P L) \text { Ratio }=\frac{\text { Non }- \text { performing loans }}{\text { Total loans }}
$$

Empirical evidence suggests that capital requirements have a significant impact on deposit and lending behaviours of a bank (Karim et al., 2014). Prior researchers such as Shehzad, Haan and Scholtens (2010) and Zhu and Yang (2016) have examined CAR in the study of state ownership and ownership concentration in their studies. In this paper, we use total capital ratio as a measure of capital adequacy. We expect banks with a greater percentage of Malaysian government ownership would have a lower CAR, which implies that the bank may have insufficient capital to absorb any potential losses. CAR can be calculated by using the formula as shown below:

$$
\text { Capital Adequacy Ratio }(C A R)=\frac{\text { Tier } 1 \text { capital }+ \text { tier } 2 \text { capital }}{\text { Risk weighed assets }}
$$

Moreover, recent studies conducted by De Haan and Van Den End (2013), Imbierowicz and Rauch (2014), and Zhu and Yang (2016) found that liquidity risk has a significant impact on bank default probability. Basel III has introduced Liquidity Coverage Ratio (LCR) to strengthen banks' liquidity profiles. However, due to data limitation, we adopt a static measure for banks' liquidity using the standard balance sheet data since the detailed breakdown of off-balance sheets is not available. Hence, the liquidity ratio is employed in this study. We expect that banks with a greater percentage of Malaysian government ownership would have a lower LR as a result of higher risk-taking. LR can be calculated by using the formula as shown below:

$$
\text { Liquidity Ratio }(L R)=\frac{\text { Liquid assets }}{\begin{array}{l}
\text { Deposits from customers and placements } \\
\text { from financial institutions }
\end{array}}
$$

\subsubsection{Moderating variables}

Three board characteristics variables have been chosen to further investigate the effect of corporate governance aspects in the study of the relationship between 
state ownership and bank's risk-taking behaviour. They are known as the board independence, foreign director and female director.

One of the most used board characteristics variable by previous researchers is board independence. The independence of directors is the central theme in governance issues. Bursa Malaysia main market listing requirements Chapter 3: Admission part 3.04 mentioned that (1) an applicant must ensure that at least 2 directors or $1 / 3$ of the board of directors of the applicant, whichever is higher, are independent directors. (2) If the number of directors of the applicant is not 3 or a multiple of 3 , then the number nearest $1 / 3$ must be used. Realising the importance of quality corporate governance, we introduce dummy as adopted in Zhu, Ye, Tucker and Chan (2016). Theoretically, banks with board independence ratio more than or equal to 0.33 should take a value of " 1 " or " 0 " otherwise. However, we find that most of the sample banks in our study have made an effort in adhering to the above requirements by having more than 0.33 independent directors in their board structure. To study the differences in board independence composition in banks' risk-taking behaviour, we have identified banks with board independence ratio more than or equal to 0.50 should take a value of " 1 " or " 0 " otherwise. This is to the extent of studying whether a larger proportion of independent directors have a greater impact on the banks' risk-taking.

Other than board independence, the dummy of foreign directors on board is also employed as one of the moderating variables in studying the relationship between state ownership and bank's risk-taking behaviour. Following Du, Jian and Lai (2017), we take a value of " 1 " if one or more directors come(s) from other countries or " 0 " otherwise.

Besides, one of the utmost popular issues examined by researchers Liu, Wei and Xie (2014), Gulamhussen and Santa (2015) and Zhu and Yang (2016) in their research study was gender diversity. We would like to know whether female director helps in bank monitoring and reduce the likelihood of excessive risk-taking. Hence, we employ the dummy of female directors as one of the moderating variables in this study. We take a value of " 1 " if there is at least one woman on the board of directors of the bank or " 0 " otherwise.

\subsubsection{Control variables}

There are three control variables employed in this study. They are: bank size, bank revenue growth and return on assets. The bank size is measured by the logarithm of the bank's total assets. This has been adopted in the studies by Anginer et al. (2018), Brandao-Marques et al. (2020), Laeven and Levine (2009), Lassoued et al. (2016), and Zhu and Yang (2016) while investigating the bank's risk-taking. The reason for controlling this variable is bank size may influence a bank's level of risk-taking. There is a possibility that larger banks may have better risk diversification and greater capacity to absorb their risk-taking. 
The revenue growth informs us how much additional annual revenue that a business can handle according to the resources in the balance sheet. Bank revenue growth is adopted as one of the control variables since every bank has a different revenue growth rate and it is believed that large banks may have higher revenue growth as they are accessible to greater resources that are available. To increase the reliability of the result conducted, we control the bank revenue growth. The bank revenue growth can be calculated by taking the first difference of the logarithm of total operating income.

The return on assets (ROA) is another control variable employed in this study. The ROA has been widely used in the previous studies while investigating the relationship between the bank's state ownership and risk-taking, such as Dong, Liu, Shen and Sun's (2016), and Lassoued et al.'s (2016). The reason for controlling this variable is because the bank's total assets may influence the incomes generated and it also gives an impact on the bank's risk-taking. There is a possibility that the banks who owned more assets will earn higher ROA and exposed to greater risks.

\subsection{Model}

Based on the above variables, Model 1 and 2 are the baseline models used in this study to regress on the relationship between state ownership and banks' risk-taking behaviour. Model 1 is used to test hypothesis 1a in which to capture the risk difference between the state-owned banks and private-owned banks. The degree of state ownership, SO is introduced in model 2 to test the degree of state ownership through GLICs on the banks' risk-taking behaviour, as shown in hypothesis $1 \mathrm{~b}$ :

$$
\begin{aligned}
\text { Risk }_{i t}= & \alpha+\beta_{1} \text { Dummy }_{\text {Soit }}+\beta_{2} \mathrm{LTA}_{i t}+\beta_{3} \mathrm{RG}_{i t}+\beta_{4} \mathrm{ROA}_{i t}+\varepsilon_{i t} \\
\text { Risk }_{i t}= & \alpha+\beta_{1} S_{i t}+\beta_{2}\left(S O \times \mathrm{Dummy}_{S o}\right)_{i t}+\beta_{3} \text { Dummy }_{\text {Soit }}+ \\
& \beta_{4} \mathrm{LTA}_{i t}+\beta_{5} \mathrm{RG}_{i t}+\beta_{6} \mathrm{ROA}_{i t}+\varepsilon_{i t}
\end{aligned}
$$

In testing for the effect of corporate governance mechanisms on banks' risktaking behaviour, we develop six models as follows: To test for the interaction effect of hypothesis 2, we add board independence variable in Model 3 and Model 4. Model 3 is used to investigate the interaction between board independence and state ownership on banks' risk-taking whereas the interaction between board independence and the degree of state ownership is tested in Model 4:

$$
\begin{aligned}
\text { Risk }_{i t}= & \alpha+\beta_{1} \text { Board }_{-} I_{i t}+\beta_{2}\left(\text { Board }_{-} I \times \text { Dummy }_{S o}\right)_{i t}+ \\
& \beta_{3} \text { Dummy }_{\text {Soit }}+\beta_{4} \mathrm{LTA}_{i t}+\beta_{5} \mathrm{RG}_{i t}+\beta_{6} \mathrm{ROA}_{i t}+\varepsilon_{i t}
\end{aligned}
$$




$$
\begin{aligned}
\operatorname{Risk}_{i t}= & \alpha+\beta_{1} \text { Board }_{-} I_{i t}+\beta_{2}\left(\text { Board }_{-} I \times S O\right)_{i t}+\beta_{3} \mathrm{SO}_{i t}+ \\
& \beta_{4} \mathrm{LTA}_{i t}+\beta_{5} \mathrm{RG}_{i t}+\beta_{6} \mathrm{ROA}_{i t}+\varepsilon_{i t}
\end{aligned}
$$

To test for the interaction effect of hypothesis 3, we add foreign director variable in Model 5 and Model 6. Model 5 is used to investigate the interaction between foreign director and state ownership on banks' risk-taking whereas the interaction between foreign director and the degree of state ownership is tested in Model 6:

$$
\begin{aligned}
& \text { Risk }_{i t}=\alpha+\beta_{1} \text { Foreign_D }_{i t}+\beta_{2}\left(\text { Foreign_D } \times \text { Dummy }_{S o}\right)_{i t}+ \\
& \beta_{3} \text { Dummy }_{\text {Soit }}+\beta_{4} \mathrm{LTA}_{i t}+\beta_{5} \mathrm{RG}_{i t}+\beta_{6} \mathrm{ROA}_{i t}+\varepsilon_{i t} \\
& \operatorname{Risk}_{i t}=\alpha+\beta_{1} \text { Foreign_D } D_{i t}+\beta_{2}(\text { Foreign_D } \times S O)_{i t}+ \\
& \beta_{3} \mathrm{SO}_{i t}+\beta_{4} \mathrm{LTA}_{i t}+\beta_{5} \mathrm{RG}_{i t}+\beta_{6} \mathrm{ROA}_{i t}+\varepsilon_{i t}
\end{aligned}
$$

To test for the interaction effect of hypothesis 4 , we add female director variable in Model 7 and Model 8. Model 7 is used to investigate the interaction between female director and state ownership on banks' risk-taking whereas the interaction between female director and the degree of state ownership is tested in Model 8:

$$
\begin{aligned}
& \text { Risk }_{i t}=\alpha+\beta_{1} \text { Female }_{-} D_{i t}+\beta_{2}\left(\text { Female }_{-} D \times \text { Dummy }_{S o}\right)_{i t}+ \\
& \beta_{3} \text { Dummy }_{\text {soit }}+\beta_{4} \mathrm{LTA}_{i t}+\beta_{5} \mathrm{RG}_{i t}+\beta_{6} \mathrm{ROA}_{i t}+\varepsilon_{i t} \\
& \text { Risk }_{i t}=\alpha+\beta_{1} \text { Female_D }_{i t}+\beta_{2}(\text { Female_D } \times S O)_{i t}+ \\
& \beta_{3} \mathrm{SO}_{i t}+\beta_{4} \mathrm{LTA}_{i t}+\beta_{5} \mathrm{RG}_{i t}+\beta_{6} \mathrm{ROA}_{i t}+\varepsilon_{i t}
\end{aligned}
$$

where $\operatorname{Risk}_{i t}$ is the risk measures for bank $i$ in year $t$. The risk measurements in the above regressions consist of NPL ratio, CAR, and LR. Dummy ${ }_{\text {SOit }}$ is the state ownership dummy for bank $i$ in year $t$ whereas $\mathrm{SO}_{i t}$ is the state ownership percentage for bank $i$ in year $t$. Board_ I is the board independence dummy for bank $i$ in year $t$. Foreign_ $\mathrm{D}_{i t}$ is the foreign director dummy for bank $i$ in year $t$. Female_ $\mathrm{D}_{i t}$ is the female director dummy for bank $i$ in year $t$. LTA $_{i t}, \mathrm{RG}_{i t}$ and $\mathrm{ROA}_{i t}$ are the control variables for bank $i$ in year $t$.

\section{Results}

\subsection{Descriptive Statistics}

Table 1 below provides the descriptive statistics for all the variables used in the model of this study. In the context of Malaysia, banks have an average of 2.16 percent NPL. CAR and LR are 15.18 percent and 17.38 percent respectively. For a comparison with similar studies conducted previously, Zhu and Yang (2016) found a substantially higher NPL (2.54\%) and LR (32.18\%), whereas 
a lower CAR (13.26\%) in China. Similar statistics are found in Shaban and James's (2018) study in Indonesia. The statistics show higher NPL (3.01\%) and LR (25.75\%), and lower CAR (11.91\%). This enlightens that Malaysia's banks have substantially lower default loans and a higher level of capital to absorb any potential losses. However, Malaysia's banks are found to have less liquid assets.

Another interesting variable worth mention is state ownership (SO). SO has a range from 12.12 percent to 66.87 percent. On average, SO owns 33.14 percent in Malaysia's banking industry. Lassoued et al. (2016) found an average of 14.49 percent SO in MENA countries whereas an average of 11.09 percent SO is found in Vietnam by Vo (2018). These numbers illuminate that the government involvement in Malaysia's banking industry is fairly high. This further motivates the researcher to examine the impact of state ownership on banks' risk-taking.

Table 1. Descriptive Statistics of Variables

\begin{tabular}{|c|c|c|c|c|c|}
\hline Variables & Obs. & Mean & Minimum & Maximum & Std. Dev. \\
\hline \multicolumn{6}{|c|}{ Risk Measures } \\
\hline NPL & 40 & 0.0216 & 0.0050 & 0.0533 & 0.0105 \\
\hline CAR & 40 & 0.1518 & 0.1203 & 0.1774 & 0.0123 \\
\hline LR & 40 & 0.1738 & 0.0492 & 0.4363 & 0.0876 \\
\hline \multicolumn{6}{|c|}{ Ownership Indicator } \\
\hline Dummy $_{\text {so }}$ & 40 & 0.5000 & 0.0000 & 1.0000 & 0.5064 \\
\hline SO & 40 & 0.3314 & 0.1212 & 0.6687 & 0.1893 \\
\hline \multicolumn{6}{|c|}{ Moderating Variables } \\
\hline Board_I & 40 & 0.7250 & 0.0000 & 1.0000 & 0.4522 \\
\hline Foreign_D & 40 & 0.8000 & 0.0000 & 1.0000 & 0.4051 \\
\hline Female_D & 40 & 0.7500 & 0.0000 & 1.0000 & 0.4385 \\
\hline \multicolumn{6}{|c|}{ Control Variables } \\
\hline TA & 40 & 0.2310 & 0.0361 & 0.7080 & 0.1750 \\
\hline RG & 40 & 0.0302 & -0.2441 & 0.3453 & 0.0753 \\
\hline ROA & 40 & 1.2450 & 0.5500 & 2.0000 & 0.3194 \\
\hline
\end{tabular}

Note: Obs. $=$ Observations, Std. Dev. $=$ Standard deviation, NPL $=$ Non-performing loans ratio, $\mathrm{CAR}=$ Capital adequacy ratio, $\mathrm{LR}=$ Liquidity ratio, Dummy $_{\mathrm{SO}}=$ State ownership dummy, SO = State ownership percentage, Board_I = Board independence dummy, Foreign_D $=$ Foreign director dummy, Female_D $=$ Female director dummy, TA $=$ Total assets (in trillions), $\mathrm{RG}=$ Revenue growth and $\mathrm{ROA}=$ Return on assets. 


\subsection{State Ownership and Banks'Risk-Taking}

Table 2. State Ownership and Banks' Risk-Taking (Baseline Model)

\begin{tabular}{|c|c|c|c|c|c|c|}
\hline Variables & NPL & & CAR & & LR & \\
\hline & (1) & (2) & (3) & (4) & (5) & (6) \\
\hline \multirow{2}{*}{ Dummy $_{\text {so }}$} & $0.0096^{* *}$ & 0.0003 & -0.0015 & $-0.0554 * * *$ & 0.0195 & -0.0059 \\
\hline & $(0.0138)$ & $(0.9810)$ & $(0.6569)$ & $(0.0043)$ & $(0.1451)$ & $(0.9650)$ \\
\hline \multirow{2}{*}{$\begin{array}{l}\text { Dummy }_{\mathrm{so}} * \\
\text { SO }\end{array}$} & & 0.1201 & & $0.2226^{*}$ & & 1.2327 \\
\hline & & $(0.2890)$ & & $(0.0530)$ & & $(0.2272)$ \\
\hline \multirow[t]{2}{*}{$\mathrm{SO}$} & & -0.1455 & & -0.1533 & & -1.7126 \\
\hline & & $(0.2071)$ & & $(0.1471)$ & & $(0.1345)$ \\
\hline \multirow[t]{2}{*}{ LTA } & -0.0055 & -0.0020 & $0.0176^{* * *}$ & $0.0098^{*}$ & $0.0602 * *$ & $0.1228^{*}$ \\
\hline & $(0.1037)$ & $(0.5886)$ & $(0.0011)$ & $(0.0593)$ & $(0.0185)$ & $(0.0600)$ \\
\hline \multirow[t]{2}{*}{ RG } & -0.0096 & $-0.0152 *$ & 0.0142 & 0.01427 & -0.0858 & -0.1623 \\
\hline & $(0.1371)$ & $(0.0735)$ & $(0.1674)$ & $(0.1528)$ & $(0.5160)$ & $(0.4765)$ \\
\hline \multirow[t]{2}{*}{ ROA } & -0.0039 & -0.0014 & 0.0040 & 0.01165 & $0.0812 *$ & 0.0610 \\
\hline & $(0.5459)$ & $(0.8822)$ & $(0.6131)$ & $(0.3292)$ & $(0.0652)$ & $(0.1854)$ \\
\hline \multirow[t]{2}{*}{ Constant } & $0.0832 * *$ & 0.0634 & -0.0508 & 0.0489 & $-0.4079 * *$ & -0.8683 \\
\hline & $(0.0114)$ & $(0.1301)$ & $(0.2943)$ & $(0.3926)$ & $(0.0477)$ & $(0.1169)$ \\
\hline Observation & 40 & 40 & 40 & 40 & 40 & 40 \\
\hline $\mathrm{R}^{2}$ & 0.2886 & 0.3260 & 0.2991 & 0.3880 & 0.2126 & 0.3096 \\
\hline
\end{tabular}

Note: $* * *, * *, *$ denote significance at $1 \%, 5 \%$ and $10 \%$ significant levels respectively. $\mathrm{NPL}=$ Non-performing loans ratio, $\mathrm{CAR}=$ Capital adequacy ratio, $\mathrm{LR}=$ Liquidity ratio, Dummy $_{\text {SO }}=$ State ownership dummy, Dummy ${ }_{\text {SO }} * \mathrm{SO}=$ Interaction of state ownership dummy and state ownership percentage, $\mathrm{SO}=$ State ownership percentage, LTA $=$ Logarithm of total assets, $\mathrm{RG}=$ Revenue growth and $\mathrm{ROA}=$ Return on assets.

Table 2 presents the regression results for the baseline models, model 1 and 2 . The regression includes all control variables and $\mathrm{R}^{2}$ is reported at the bottom of the table. Column 1, 3, 5 in Table 2 shows the SOBs' baseline result as compared with the POBs. Based on column 1 in Table 2, SOBs are associated with significantly higher non-performing loans (NPL) ratio of 0.0096 percent compared with the POBs, at 95 percent confidence level. The other two risktaking measurements, however, are not significant. Hence, we do not find strong evidence to support hypothesis 1a. Column 2, 4 and 6 is the model used to test the interaction of dummy and the degree of state ownership. The results show 
that the interaction of dummy and state ownership only significant in terms of Capital Adequacy Ratio (CAR). The significant positive coefficient of 0.2226 in column 4 suggests that a higher degree of state ownership tends to improve CAR. In addition, the results are found to have no significant impact on banks' NPLs and LR. Thus, hypothesis $1 \mathrm{~b}$ is rejected.

As for the bank size, the results reveal that larger banks tend to have higher capital adequacy and liquidity, hence lowering the risk-taking behaviour. This is according to the literature that larger banks have better risk diversification and able to reduce high risk-taking activities.

\subsection{Board Independence and State Ownership on Banks'Risk-Taking}

Table 3 presents the regression result of the effect of board independence in the relationship between state ownership and banks' risk-taking. The result shows that when more than half of the board of directors were independent directors, it has significant positive impacts on NPL ratio and liquidity ratio (LR) with a coefficient of 0.0112 and 0.1856 at 95 percent confidence level and 99 percent confidence level respectively.

Table 3. The Effect of Board Independence and State Ownership on Banks' Risk-Taking

\begin{tabular}{|c|c|c|c|}
\hline Variables & NPL & CAR & LR \\
\hline Board_I & $\begin{array}{l}-0.0093 * * \\
(0.0135)\end{array}$ & $\begin{array}{l}0.0004 \\
(0.9061)\end{array}$ & $\begin{array}{l}-0.1273 * * * \\
(0.0024)\end{array}$ \\
\hline Board_I * Dummy & $\begin{array}{l}0.0112 * * \\
(0.0168)\end{array}$ & $\begin{array}{l}-0.0085 \\
(0.2437)\end{array}$ & $\begin{array}{l}0.1856^{* * * *} \\
(0.0000)\end{array}$ \\
\hline Dummy $_{\text {so }}$ & $\begin{array}{l}0.0051 \\
(0.2381)\end{array}$ & $\begin{array}{l}0.0051 \\
(0.4389)\end{array}$ & $\begin{array}{l}-0.0674 * * * \\
(0.0000)\end{array}$ \\
\hline LTA & $\begin{array}{l}-0.0076^{*} \\
(0.0888)\end{array}$ & $\begin{array}{l}0.0182 * * * \\
(0.0001)\end{array}$ & $\begin{array}{l}0.0284 * \\
(0.0891)\end{array}$ \\
\hline RG & $\begin{array}{l}-0.0145^{* *} \\
(0.0476)\end{array}$ & $\begin{array}{l}0.0153 \\
(0.2258)\end{array}$ & $\begin{array}{l}-0.1563 \\
(0.1315)\end{array}$ \\
\hline ROA & $\begin{array}{l}0.0018 \\
(0.8283)\end{array}$ & $\begin{array}{l}0.0030 \\
(0.6030)\end{array}$ & $\begin{array}{l}-0.0002 \\
(0.9957)\end{array}$ \\
\hline Constant & $\begin{array}{l}0.1049 * * \\
(0.0169)\end{array}$ & $\begin{array}{l}-0.0562 \\
(0.1894)\end{array}$ & $\begin{array}{l}-0.0925 \\
(0.5024)\end{array}$ \\
\hline Observation & 40 & 40 & 40 \\
\hline $\mathrm{R}^{2}$ & 0.3706 & 0.3273 & 0.4530 \\
\hline
\end{tabular}

Note: $* * *, * * *$ denote significance at $1 \%, 5 \%$ and $10 \%$ significant levels respectively. $\mathrm{NPL}=$ Non-performing loans ratio, $\mathrm{CAR}=$ Capital adequacy ratio, $\mathrm{LR}=$ Liquidity ratio, 
Board_I $=$ Board independence dummy, Dummy ${ }_{\mathrm{SO}}=$ State ownership dummy, Board_I * Dummy $_{\text {So }}=$ Interaction of board independence dummy and state ownership dummy, LTA $=$ Logarithm of total assets, $\mathrm{RG}=$ Revenue growth and $\mathrm{ROA}=$ Return on assets.

However, the board independence is found to have no significant impact on CAR. Hypothesis 2 of this study could not be rejected as the board independence significantly affects the impact of ownership by Malaysian government on banks' risk-taking behaviour. Evidently, the risk-taking measurements show that the two risk-taking proxies out of the three are significant.

The impact of board independence and the degree of state ownership is presented in Table 4 . The finding in Table 4 is consistent with Table 3 where greater state ownership involvement in banks is associated with a statistically significant higher LR of 0.5133 percent.

Table 4. The Effect of Board Independence and Degree of State Ownership on Banks' Risk-Taking

\begin{tabular}{llll}
\hline Variables & NPL & CAR & LR \\
\hline Board_I & $-0.0111^{* *}$ & 0.0020 & $-0.1960^{* * *}$ \\
& $(0.0476)$ & $(0.7130)$ & $(0.0004)$ \\
Board_I* SO & 0.0237 & -0.0195 & $0.5133^{* * *}$ \\
& $(0.1018)$ & $(0.2498)$ & $(0.0000)$ \\
SO & 0.0146 & 0.0196 & $-0.2491^{* * *}$ \\
& $(0.2556)$ & $(0.2483)$ & $(0.0000)$ \\
LTA & $-0.0104 *$ & $0.0165^{* * *}$ & 0.0130 \\
RG & $(0.0792)$ & $(0.0003)$ & $(0.6215)$ \\
& -0.0118 & 0.0160 & $-0.1545^{* *}$ \\
ROA & $(0.2786)$ & $(0.1517)$ & $(0.0430)$ \\
Constant & -0.0012 & 0.0063 & -0.0257 \\
& $(0.8911)$ & $(0.2855)$ & $(0.5562)$ \\
Observation & $0.1369 * *$ & -0.0451 & 0.1541 \\
R & $(0.0163)$ & $(0.2525)$ & $(0.5269)$ \\
\hline
\end{tabular}

Note: $* * *, * *, *$ denote significance at $1 \%, 5 \%$ and $10 \%$ significant levels respectively. $\mathrm{NPL}=$ Non-performing loans ratio, $\mathrm{CAR}=$ Capital adequacy ratio, $\mathrm{LR}=$ Liquidity ratio, Board_I = Board independence dummy, SO = State ownership percentage, Board_I * $\mathrm{SO}=$ Interaction of board independence dummy and state ownership percentage, $\mathrm{LTA}=$ Logarithm of total assets, $\mathrm{RG}=$ Revenue growth and $\mathrm{ROA}=$ Return on assets. 


\subsection{Foreign Director and State Ownership on Banks'Risk-Taking}

Table 5 presents the regression result of the effect of foreign directors on the relationship between state ownership and banks' risk-taking. The result shows that SOBs, on average, have a lower NPL ratio compared to the POBs by a magnitude of 0.0230 percent when there is the presence of foreign director on board. However, the foreign director is found to have no significant impact on CAR and LR. Since the findings of two risk-taking proxies out of the three are not significant, hence Hypothesis 3 is rejected. The impact of foreign director and the degree of state ownership is presented in Table 6 . The finding in Table 6 is consistent with Table 5 where greater state ownership involvement in banks is associated with a statistically significant lower NPL ratio of 0.0719 percent.

Table 5. The Effect of Foreign Director and State Ownership on Banks' RiskTaking

\begin{tabular}{llll}
\hline Variables & NPL & CAR & LR \\
\hline Foreign_D & $0.0168^{* *}$ & 0.0152 & $0.0805^{* * *}$ \\
& $(0.0345)$ & $(0.1930)$ & $(0.0033)$ \\
Foreign_D* Dummy $_{\text {so }}$ & $-0.0230^{* * *}$ & -0.0169 & -0.0641 \\
& $(0.0007)$ & $(0.2376)$ & $(0.2883)$ \\
Dummy $_{\text {SO }}$ & $0.0313^{* * *}$ & 0.0152 & 0.0882 \\
LTA & $(0.0006)$ & $(0.2930)$ & $(0.1633)$ \\
& -0.0021 & $0.0203^{* * *}$ & $0.0716^{* * *}$ \\
RG & $(0.3946)$ & $(0.0000)$ & $(0.0063)$ \\
& -0.0121 & $0.0135^{* *}$ & -0.0782 \\
ROA & $(0.1764)$ & $(0.0127)$ & $(0.4354)$ \\
& 0.0081 & 0.0153 & -0.0178 \\
Constant & $(0.4246)$ & $(0.3339)$ & $(0.6625)$ \\
& 0.0158 & $-0.1080^{* * *}$ & $-0.6863^{* * *}$ \\
Observation & $(0.2143)$ & $(0.0000)$ & $(0.0058)$ \\
$\mathrm{R}^{2}$ & 40 & 40 & 40 \\
\hline
\end{tabular}

Note: $* * *, * * *$ denote significance at $1 \%, 5 \%$ and $10 \%$ significant levels respectively. $\mathrm{NPL}=$ Non-performing loans ratio, $\mathrm{CAR}=$ Capital adequacy ratio, $\mathrm{LR}=$ Liquidity ratio, Foreign_D $=$ Foreign director dummy, Dummy ${ }_{\text {so }}=$ State ownership dummy, Foreign_D

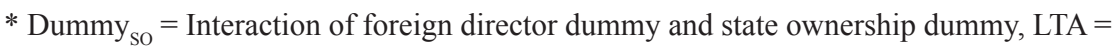
Logarithm of total assets, $\mathrm{RG}=$ Revenue growth and $\mathrm{ROA}=$ Return on assets. 
Table 6. The Effect of Foreign Director and Degree of State Ownership on Banks' Risk-Taking

\begin{tabular}{llll}
\hline Variables & NPL & CAR & LR \\
\hline \multirow{2}{*}{ Foreign_D } & $0.0279^{* *}$ & 0.0241 & $0.1188^{*}$ \\
Foreign_D* SO & $(0.0171)$ & $(0.1972)$ & $(0.0660)$ \\
& $-0.0719^{* * *}$ & -0.0515 & -0.2306 \\
SO & $(0.0011)$ & $(0.2391)$ & $(0.2641)$ \\
& $0.0866^{* * *}$ & 0.0506 & 0.2043 \\
LTA & $(0.0011)$ & $(0.2361)$ & $(0.3008)$ \\
& -0.0020 & $0.0196^{* * *}$ & $0.0929^{* * *}$ \\
RG & $(0.4287)$ & $(0.0000)$ & $(0.0093)$ \\
& -0.0128 & $0.0140^{* * *}$ & -0.0966 \\
ROA & $(0.1948)$ & $(0.0013)$ & $(0.4293)$ \\
& 0.0039 & 0.0170 & -0.0522 \\
Constant & $(0.6866)$ & $(0.2675)$ & $(0.1860)$ \\
& 0.0077 & $-0.1119^{* * *}$ & $-0.9005^{* *}$ \\
Observation & $(0.5498)$ & $(0.0000)$ & $(0.0168)$ \\
$\mathrm{R}^{2}$ & 40 & 40 & 40 \\
\hline
\end{tabular}

Note: $* * * * *, *$ denote significance at $1 \%, 5 \%$ and $10 \%$ significant levels respectively. $\mathrm{NPL}=$ Non-performing loans ratio, $\mathrm{CAR}=$ Capital adequacy ratio, $\mathrm{LR}=$ Liquidity ratio, Foreign_D $=$ Foreign director dummy, SO $=$ State ownership percentage, Foreign_D * $\mathrm{SO}=$ Interaction of foreign director dummy and state ownership percentage, LTA = Logarithm of total assets, $\mathrm{RG}=$ Revenue growth and $\mathrm{ROA}=$ Return on assets.

\subsection{Female Director and State Ownership on Banks' Risk-Taking}

Table 7 presents the regression result of the effect of female director in the relationship between state ownership and banks' risk-taking. The result shows that when there is presence of female director on board, it has a significant negative impact on LR with a coefficient of 0.0859 at 95 percent confidence level. However, the female director is found to have no significant impact on NPL and CAR when it interacts with state ownership. On the other hand, the result in Table 8 shows that greater state ownership involvement in banks is associated with a significantly higher CAR of 0.0287 percent. Hypothesis 4 of this study is rejected as the evidence by the risk-taking measurements shows that the two risk-taking proxies out of the three are not significant. 


\subsection{Findings}

From the regression results shown above, firstly, we find significant and positive relationships between the state ownership and non-performing loans (NPL) ratio. As compared to the $\mathrm{POBs}$, SOBs are associated with a significantly higher

NPL ratio. This indicates that the SOBs tend to take higher risks in providing loans. This finding is consistent with the social lending view where the SOBs tend to focus on developing nations and allocating too much funds to projects that comes with high social returns and improving general welfare. However, we could see a significant positive impact on capital adequacy ratio (CAR) when there is interaction from the degree of state ownership. This finding suggests that a higher degree of state ownership tends to improve the level of capital in banks. On the other hand, we do not find significant impact on banks' liquidity ratio (LR). This finding is unexpected and suggests that the Malaysian government ownership in banks does not have a direct relationship with the banks' liquidity risk. One possible explanation is that the state shareholders concern more on the banks' solvency rather than the banks' liquidity position. While the shareholders are pursuing on pecuniary interests, they may have overlooked the banks' liquidity position. This might increase any potential financial distress in the future.

Secondly, we expand the study to examine the effect of corporate governance mechanisms in the relationship between state ownership and banks' risk-taking through board independence. The results show that SOBs with board independence ratio more than or equal to 0.50 are associated with higher NPL ratio. Consistent with the social lending view, the presence of ownership by the Malaysian government significantly affects the decision making made by the board, incurring higher risk in lending out loans. Although the ownership by the Malaysian government has no direct impact on banks' LR, it has impacts on banks' LR through the channel of board independence. The evidence shows that independent directors in SOBs attribute to lower liquidity risk. We further test and find that a higher degree of state ownership has a greater impact on LR. This finding is supported by Rosenstein and Wyatt (1990), Klein (2002) and Nguyen and Nielsen (2010), suggesting that the intervention from Malaysian government and outside directors has foster efficiency in supervising and advising functions in terms of liquidity assets and liabilities. Hence, reduce the likelihood of liquidity risk.

Thirdly, we examine the effect of foreign director in the relationship between state ownership and risk-taking behaviour. The results show that the presence of foreign director in SOBs is associated with lower credit risk due to the need to adhere to risk management policies and procedures designed and implemented by the banks. Gillian and Starks (2003) revealed that foreign director plays a more active role in upholding better firm-level governance in reducing information asymmetry and strengthening a firm's transparency which may have an impact on the firm's investment policy. Moreover, we could see risk reduction to a greater extent when the Malaysian government ownership is 
higher. Although we do not find evidence on the interaction of foreign director and state ownership on LR, we find similar finding in the individual effect of foreign director. The result suggests that the presence of foreign director tends to improve the banks' liquidity.

Lastly, we examine the effect of female director and the results show that SOBs are associated with higher liquidity risk with the presence of female director. However, there is evidence that banks' capital adequacy tends to improve when there is a higher degree of intervention by the Malaysian government. A possible explanation is the adoption of Basel III Accords in Malaysia. Although the implementation only begins in 2013, the Malaysian government has imposed strict regulations to ensure banks' managers have attended to the requirements increment and started to adhere in placing a better capital prior to the full adoption of Basel III Accords. Being comply with stricter capital requirements, it shows that the CAR in Malaysian banks can be further improved in years to come.

In short, SOBs' risk-taking could be mitigated through $\mathrm{CG}$ mechanisms. Although there is no strong evidence to support across all three risk-taking proxies in this study, we find that the banks' liquidity is strengthened with the presence of independent directors. Moreover, the credit risk is reduced with the presence of foreign director on board. This enlightens the fact that effective bank governance from the board of directors' supervision is somehow crucial in mitigating Malaysian banks' risk-taking.

Table 7. The Effect of Female Director and State Ownership on Banks' RiskTaking

\begin{tabular}{llll}
\hline Variables & NPL & CAR & LR \\
\hline Female_D & -0.0002 & $-0.0110^{* *}$ & $0.0804 * * *$ \\
& $(0.9433)$ & $(0.0104)$ & $(0.0000)$ \\
Female_D * Dummy $_{\text {SO }}$ & 0.0022 & 0.0101 & $-0.0859^{* *}$ \\
& $(0.5430)$ & $(0.1753)$ & $(0.0493)$ \\
Dummy $_{\text {SO }}$ & 0.0082 & $-0.0103^{*}$ & $0.0910^{* * *}$ \\
& $(0.1278)$ & $(0.0577)$ & $(0.0006)$ \\
LTA & -0.0061 & $0.0231^{* * *}$ & 0.0247 \\
& $(0.2693)$ & $(0.0000)$ & $(0.4224)$ \\
RG & -0.0097 & $0.0159 *$ & -0.0980 \\
& $(0.1317)$ & $(0.0907)$ & $(0.5013)$ \\
ROA & -0.0034 & 0.0027 & $-0.0750^{*}$ \\
& $(0.6499)$ & $(0.6559)$ & $(0.0953)$ \\
Constant & $0.0902^{*}$ & $-0.1020^{* * *}$ & -0.0784 \\
& $(0.0932)$ & $(0.0100)$ & $(0.7815)$ \\
Observation & 40 & 40 & 40 \\
$\mathrm{R}^{2}$ & 0.2912 & 0.3645 & 0.2858 \\
\hline
\end{tabular}


Note: $* * *, * * *$ denote significance at $1 \%, 5 \%$ and $10 \%$ significant levels respectively. $\mathrm{NPL}=$ Non-performing loans ratio, $\mathrm{CAR}=$ Capital adequacy ratio, $\mathrm{LR}=$ Liquidity ratio, Female_D $=$ Female director dummy, Dummy ${ }_{\text {So }}=$ State ownership dummy, Female_D

* Dummy $_{\text {so }}=$ Interaction of female director dummy and state ownership dummy, LTA = Logarithm of total assets, $\mathrm{RG}=$ Revenue growth and $\mathrm{ROA}=$ Return on assets.

Table 8. The Effect of Female Director and Degree of State Ownership on Banks' Risk-Taking

\begin{tabular}{llll}
\hline Variables & NPL & CAR & LR \\
\hline Female_D & 0.0012 & $-0.0147^{* *}$ & $0.1158^{* * *}$ \\
& $(0.7712)$ & $(0.0116)$ & $(0.0011)$ \\
Female_D* SO & -0.0007 & $0.0287^{*}$ & -0.2603 \\
& $(0.9496)$ & $(0.0906)$ & $(0.1015)$ \\
SO & 0.0241 & -0.0276 & $0.2427 * * *$ \\
& $(0.2196)$ & $(0.1239)$ & $(0.0036)$ \\
LTA & -0.0078 & $0.0229 * * *$ & 0.0304 \\
RG & $(0.2329)$ & $(0.0000)$ & $(0.4801)$ \\
& -0.0086 & $0.0162^{*}$ & -0.1025 \\
ROA & $(0.3111)$ & $(0.0578)$ & $(0.5284)$ \\
Constant & -0.0055 & 0.0036 & $-0.0887 *$ \\
& $(0.4784)$ & $(0.5743)$ & $(0.0861)$ \\
Observation & $0.1078 *$ & $-0.0977 * *$ & -0.1524 \\
R2 & $(0.0750)$ & $(0.0299)$ & $(0.7081)$ \\
\hline
\end{tabular}

Note: $* * *, * *, *$ denote significance at $1 \%, 5 \%$ and $10 \%$ significant levels respectively. $\mathrm{NPL}=$ Non-performing loans ratio, $\mathrm{CAR}=$ Capital adequacy ratio, $\mathrm{LR}=$ Liquidity ratio, Female_D $=$ Female director dummy, SO $=$ State ownership percentage, Female_D * SO $=$ Interaction of female director dummy and state ownership percentage, LTA $=$ Logarithm of total assets, $\mathrm{RG}=$ Revenue growth and $\mathrm{ROA}=$ Return on assets.

\subsection{Robustness Checks}

The panel regression model is reexamined using the Generalized Method of Moments (GMM) estimation since the results presented earlier may subject to endogeneity and unobservable time-invariant individual effects. Following Roodman (2009), this paper employs the two-step system GMM. The robustness result is presented in Table 9. The GMM result shows that most of the signs are consistent with the baseline result presented in Table 2, only the level of significance differs. The robustness result strengthens the finding of hypothesis 
1a. This is evidence by greater credit risk and lower level of capital. Besides, the control variables become more significant after the inclusion of lag variables. The result highlights that the banks that are larger in size and the banks that are more capable at earning the revenue using assets, are exposed to lower risks.

Table 9. Robustness Check

\begin{tabular}{|c|c|c|c|c|c|c|}
\hline Variables & NPL & & CAR & & LR & \\
\hline & (1) & (2) & (3) & (4) & (5) & (6) \\
\hline \multirow{2}{*}{ Dummy $_{\text {so }}$} & $0.0669 * * *$ & 0.0130 & $-0.0413 * * *$ & -0.0847 & $0.3682^{* * *}$ & -0.7731 \\
\hline & $(0.0000)$ & $(0.9112)$ & $(0.0006)$ & $(0.4103)$ & $(0.0020)$ & $(0.3867)$ \\
\hline \multirow[t]{2}{*}{ Dummy $_{\text {so }} * \mathrm{SO}$} & & 0.1925 & & 0.5267 & & 8.6280 \\
\hline & & $(0.8311)$ & & $(0.2373)$ & & $(0.1410)$ \\
\hline \multirow[t]{2}{*}{ SO } & & -0.2441 & & -0.4523 & & $-9.8971 *$ \\
\hline & & $(0.8070)$ & & $(0.1775)$ & & $(0.0861)$ \\
\hline \multirow[t]{2}{*}{ LTA } & $-0.0375 * * *$ & -0.0177 & $0.0622 * * *$ & $0.0613 * * *$ & -0.0670 & 0.0704 \\
\hline & $(0.0023)$ & $(0.6614)$ & $(0.0001)$ & $(0.0021)$ & $(0.6179)$ & $(0.7541)$ \\
\hline \multirow[t]{2}{*}{ RG } & -0.1048 & -0.1206 & 0.1160 & $0.5014 * * *$ & -0.1961 & -1.2725 \\
\hline & $(0.4863)$ & $(0.4594)$ & $(0.4422)$ & $(0.0009)$ & $(0.6989)$ & $(0.4215)$ \\
\hline \multirow[t]{2}{*}{ ROA } & $-0.0483 * *$ & -0.0245 & $0.0341 * *$ & 0.0096 & $0.3999 * * *$ & 0.0503 \\
\hline & $(0.0114)$ & $(0.6869)$ & $(0.0364)$ & $(0.8045)$ & $(0.0022)$ & $(0.8697)$ \\
\hline \multirow[t]{2}{*}{ Constant } & $0.3460 * * *$ & 0.2161 & $-0.4866^{* * *}$ & $-0.5948 * * *$ & 0.1933 & 0.8273 \\
\hline & $(0.0041)$ & $(0.5591)$ & $(0.0086)$ & $(0.0084)$ & $(0.9020)$ & $(0.7642)$ \\
\hline \multirow[t]{2}{*}{$\begin{array}{l}\mathrm{AR}(1) \text { test } \\
\text { statistic }\end{array}$} & $-0.5200 *$ & $-0.7985^{* *}$ & $-0.2983^{*}$ & $-1.4643^{*}$ & $-0.6734 *$ & $-1.5671 *$ \\
\hline & $(0.0603)$ & $(0.0425)$ & $(0.0766)$ & $(0.0943)$ & $(0.0501)$ & $(0.0871)$ \\
\hline \multirow[t]{2}{*}{$\begin{array}{l}\text { AR(2) test } \\
\text { statistic }\end{array}$} & -1.1620 & -0.2008 & -1.2582 & -1.0004 & -0.0872 & -0.5830 \\
\hline & $(0.2452)$ & $(0.8409)$ & $(0.2083)$ & $(0.3171)$ & $(0.9305)$ & $(0.5599)$ \\
\hline Hansen test of & 2.4087 & 4.1272 & 2.3782 & 1.7791 & 1.5028 & 3.3094 \\
\hline $\begin{array}{l}\text { over- } \\
\text { identification }\end{array}$ & $(0.6610)$ & $(0.8455)$ & $(0.6666)$ & $(0.9871)$ & $(0.8262)$ & $(0.9135)$ \\
\hline
\end{tabular}

Note: $* * * * *, *$ denote significance at $1 \%, 5 \%$ and $10 \%$ significant levels respectively. $\mathrm{NPL}=$ Non-performing loans ratio, $\mathrm{CAR}=$ Capital adequacy ratio, $\mathrm{LR}=$ Liquidity ratio,

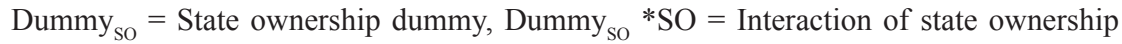
dummy and state ownership percentage, $\mathrm{SO}=$ State ownership percentage, LTA = Logarithm of total assets, $\mathrm{RG}=$ Revenue growth and $\mathrm{ROA}=$ Return on assets. 


\section{Conclusion and Implications}

The objective of this study is to investigate how state ownership affects banks' risk-taking behaviour with a sample of banks in Malaysia. In summary, we find that state government incurred higher risk-taking behaviour in creating and lending out loans. This is consistent with the social lending view which shows that state-owned banks are more likely to focus on developing nations and lending out loans to project that comes with high social returns. The robustness result strengthens this finding, indicating that state-owned banks are associated with higher risk-taking behaviour. However, the banks' risk-taking can be lower with more effective governance from the board of directors. Also, there is evidence that a higher degree of state ownership has a more significant impact on the banks' risk-taking behaviour.

In facing poor earnings prospects in the current challenging economic environment, this paper shares important implications for Malaysia's banking industry. The government involvement through GLICs ownership in local commercial banks was seen as an important move to mitigate the increasing downside risks to Malaysia's economic development. This can be done through maintaining an optimal level of decision making. In relation to the significant impact of how excessive risk-taking behaviour by banks has an effect on the national economy in the previous financial crises, the Malaysian banks should mitigate high risk-taking particularly in relative to loans portfolio.

On the other hand, the bank management should remain focused on maintaining a healthy liquid position by building an efficient capital structure and liquidity management in banks. Even the findings show that state shareholders concern more on banks' solvency, thus, the importance of liquidity position placed in banks should not be neglected. The ease availability of liquid funds is crucial at all times.

Last but not least, the findings of this paper suggest that the supervision from the board of directors, somehow plays a crucial role in reducing the banks' risk-taking behaviour. Reviewing the board of directors' structure can help to monitor the banks' activities and tackle the flaw of corporate governance mechanisms which is very relevant in the context of Malaysia where state-owned banks are one of the drivers of the economic development.

\section{Endnotes}

1 The data are extracted from Malaysia Banking Industry Report 1H2011 published by Emerging Markets Direct. 
2 Shares ownership data are extracted from Bursa Malaysia Banks’ 2015 Annual Report.

\section{Acknowledgments}

This work was supported by the USM Fellowship provided by the Institute of Postgraduate Studies, Universiti Sains Malaysia.

\section{References}

Abdul Rahman, N.A., \& Rejab,A. F. (2013). The effect of risk taking on ownership structure and bank performance: A Malaysia case. International Review of Business Research Papers, 9(6), 68-82.

Abdul Razak, N. H., Ahmad, R., \& Aliahmed, H. J. (2008). Government ownership and performance: An analysis of listed companies in Malaysia. Corporate Ownership and Control, 6(2), 434-442.

Abdul Razak, N. H. (2011). Government ownership and corporate performance: A comparative analysis of Malaysian and Singaporean listed companies (Doctoral thesis, University of Malaya, Kuala Lumpur, Malaysia). University of Malaya Research Repository. Retrieved from http:// studentsrepo.um.edu.my/id/eprint/1703

Adams, R. B., \& Ferreira, D. (2009). Women in the boardroom and their impact on governance and performance. Journal of Financial Economics, 94(2), 291-309.

Anderson, R. C., Mansi, S. A., \& Reeb, D. M. (2004). Board characteristics, accounting report integrity, and the cost of debt. Journal of Accounting and Economics, 37(3), 315-342.

Anginer, D., Demirguc-Kunt, A., Huizinga, H., \& Ma, K. (2018). Corporate governance of banks and financial stability. Journal of Financial Economics, 130(2), 327-346.

Athanasoglou, P. P., Brissimis, S. N., \& Delis, M. D. (2008). Bank-specific, industry-specific and macroeconomic determinants of bank profitability. Journal of International Financial Markets Institutions and Money Institutions and Money, 18(2), 121-136. 
Barr, R. S., Seiford, L. M., \& Siems, T. F. (1994). Forecasting bank failure: A non-parametric frontier estimation approach. Recherches Economiques de Louvain/Louvain Economic Review, 60(4), 417-429.

Berger, A. N., Clarke, G. R., Cull, R., Klapper, L. F., \& Udell, G. F. (2005). Corporate governance and bank performance: Ajoint analysis of the static, selection, and dynamic effects of domestic, foreign, and state ownership. Journal of Banking \& Finance, 29(8-9), 2179-2221.

Berger, A. N., Hasan, I., \& Zhou, M. (2009). Bank ownership and efficiency in China: What will happen in the world's largest nation? Journal of Banking \& Finance, 33(1), 113-130.

Brandao-Marques, L., Correa, R., \& Sapriza, H. (2020). Government support, regulation, and risk taking in the banking sector. Journal of Banking \& Finance, 112(March), article 105284.

Chin, Y. W. (2015). Changes of ownership and identities of Malaysian banks: Ethnicity, state and globalization (Copenhagen Discussion Papers No. 51). Retrieved from https://www.econstor.eu/bitstream/10419/208649/1/ cbs-cdp2015-51.pdf

Cornett, M. M., Guo, L., Khaksari, S., \& Tehranian, H. (2010). The impact of state ownership on performance differences in privately-owned versus state-owned banks: An international comparison. Journal of Financial Intermediation, 19(1), 74-94.

De Haan, L., \& Van Den End, J. W. (2013). Bank liquidity, the maturity ladder, and regulation. Journal of Banking \& Finance, 37(10), 3930-3950.

Demirguc-Kunt, A. (1989). Deposit-institution failures: A review of empirical literature. Economic Review, 25(4), 2-18.

Dong, Y., Liu, Z. T., Shen, Z., \& Sun, Q. (2016). Does state ownership really matter in determining access to bank loans? Evidence from China's partial privatization. Pacific-Basin Finance Journal, 40(Part A), 73-85.

Du, X., Jian, W., \& Lai, S. (2017). Do foreign directors mitigate earnings management? Evidence from China. International Journal of Accounting, 52(2), 142-177.

Ezat, A., \& El-Masry, A. (2008). The impact of corporate governance on the timeliness of corporate internet reporting by Egyptian listed companies. Managerial Finance, 34(12), 848-867.

Gillan, S. L., \& Starks, L. T. (2003). Corporate governance, corporate ownership, and the role of institutional investors: A global perspective. Journal of Applied Finance, 13(2), 4-22. 
Global Financial Development Report. (2019/2020). Bank regulation and supervision a decade after the global financial crisis. World Bank. Retrieved from https://openknowledge.worldbank.org/bitstream/handle/ 10986/28482/9781464811487.pdf

Gomez, E. T. (2005). The state, governance and corruption in Malaysia. In Nicholas Tarling (Ed.), Corruption and good governance in Asia (pp. 214-244). London: Routledge.

Gomez, E. T., Padmanabhan, T., Kamaruddin, N., Bhalla, S., \& Fisal, F. (2018). Minister of Finance Incorporated: Ownership and control of corporate Malaysia. Singapore: Palgrave Macmillan.

Gulamhussen, M. A., \& Santa, S. F. (2015). Female directors in bank boardrooms and their influence on performance and risk-taking. Global Finance Journal, 28, 10-23.

Haggarty, L., \& Shirley M. M. (1997). Anew data base on state-owned enterprises. The World Bank Economic Review, 11(3), 491-513.

Hamid, A. A. (2011). The corporate governance structures of GLCs and NGLCs and firm performance in Malaysia. Social and Management Research Journal, 8(2), 1-28.

Hossain, M., Jain, P. K., \& Mitra, S. (2013). State ownership and bank equity in the Asia-Pacific region. Pacific-Basin Finance Journal, 21(1), 914-931.

Iannota, G., Nocera, G., \& Sironi, A. (2007). Ownership structure, risk and performance in the European banking industry. Journal of Banking \& Finance, 31(7), 2127-2149.

Iannotta, G., Nocera, G., \& Sironi, A. (2013). The impact of government ownership on bank risk. Journal of Financial Intermediation, 22(2), 152176.

Imbierowicz, B., \& Rauch, C. (2014). The relationship between liquidity risk and credit risk in banks. Journal of Banking \& Finance, 40, 242-256.

Jensen, M. C., \& Meckling, W. H. (1976). Theory of the firm: Managerial behavior, agency cost and ownership structure. Journal of Financial Economics, 3(4), 305-360.

Jiraporn, P., Chatjuthamard, P., Tong, S., \& Kim, Y. S. (2015). Does corporate governance influence corporate risk-taking? Evidence from the Institutional Shareholders Services (ISS). Finance Research Letters, 13, 105-112.

Karim, M. A., Hassan, M. K., Hassan, T., \& Mohamad, S. (2014). Capital adequacy and lending and deposit behaviors of conventional and islamic banks. Pacific-Basin Finance Journal, 28, 58-75. 
Klein, A. (2002). Audit committee, board of director characteristics, and earnings management. Journal of Accounting and Economics, 33(3), 375-400.

Koudstaal, M., \& Wijnbergen, S. V. (2012). On risk, leverage and banks: Do highly leveraged banks take on excessive risk? (SSRN Working paper 2170008). Retrieved from https://papers.tinbergen.nl/12022.pdf

Krugman, P. (2009). The return of depression economics and the crisis of 2008. New York: W. W. Norton \& Company.

Laeven, L., \& Levine, R. (2009). Bank governance, regulation and risk taking. Journal of Financial Economics, 93(2), 259-275.

Lassoued, N., Sassi, H., \& Ben Rejeb Attia, M. (2016). The impact of state and foreign ownership on banking risk: Evidence from the MENA countries. Research in International Business and Finance, 36, 167-178.

Lee, A.-X., \& Hooy, C.-W. (2020). Banks' risk-taking and state ownership: Evidence from Asian emerging markets. Malaysian Journal of Economic Studies, 57(1), 59-80.

Liang, Q., Xu, P., \& Jiraporn, P. (2013). Board characteristics and Chinese bank performance. Journal of Banking \& Finance, 37(8), 2953-2968.

Liu, Y., Wei, Z., \& Xie, F. (2014). Do women directors improve firm performance in China? Journal of Corporate Finance, 28, 169-184.

Naima, L., Houda, S., \& Mouna, B. R. A. (2016). The impact of state and foreign ownership on banking risk: Evidence from the MENA countries. Research in International Business and Finance, 36, 167-178.

Najid, N. A., \& Rahman, R. A. (2011). Government ownership and performance of Malaysian government-linked companies. International Research Journal of Finance and Economics, 61(1), 1450-2887.

Nguyen, B. D., \& Nielsen, K. M. (2010). The value of independent directors: Evidence from sudden death. Journal of Financial Economics, 98(3), 550-567.

OECD. (2006). Policy brief on corporate governance of banks in Asia. Paris: OECD Publishing.

OECD. (2013). OECD Investment Policy Reviews: Malaysia 2013. Paris: OECD Publishing.

Raheja, C. G. (2005). Determinants of board size and composition: A theory of corporate boards. Journal of Financial and Quantitative Analysis, 40(2), 283-306. 
Reinhart, C. M., \& Rogoff, K. S. (2011). From financial crash to debt crisis. American Economic Review, 101(5), 1676-1706.

Roodman, D. (2009). How to do xtabond2: An introduction to difference and system GMM in Stata. Stata Journal, 9(1), 86-136.

Rosenstein, S., \& Wyatt, J. G. (1990). Outside directors, board independence, and shareholder wealth. Journal of Financial Economics, 26(2), 175-191.

Samaha, K., Dahawy, K., Hussainey, K., \& Stapleton, P. (2012). The extent of corporate governance disclosure and its determinants in a developing market: The case of Egypt. Advances in Accounting, 28(1), 168-178.

Shaban, M., \& James, G. A. (2018). The effects of ownership change on bank performance and risk exposure: Evidence from Indonesia. Journal of Banking \& Finance, 88, 483-497.

Shehzad, C. T., Haan, J. D., \& Scholtens, B. (2010). The impact of bank ownership concentration on impaired loans and capital adequacy. Journal of Banking \& Finance, 34(2), 399-408.

Shleifer, A., \& Vishny, R. W. (1986). Large shareholders and corporate control. Journal of Political Economy, 94(3), 461-488.

Shleifer, A., \& Vishny, R. W. (1994). Politicians and firms. Quarterly Journal of Economics, 109(4), 995-1025.

Stiglitz, J. E. (1993). The role of the state in financial markets. The World Bank Economic Review, 7(suppl_1), 19-52.

Taufil-Mohd, K. N., Md-Rus, R., \& Musallam, S. R. M. (2013). The effect of ownership structure on firm performance in Malaysia. International Journal of Finance and Accounting, 2(2), 75-81.

Uddin, M. H. (2016). Effect of government share ownership on corporate risk taking: Case of the United Arab Emirates. Research in International Business and Finance, 36, 322-339.

Vo, X. V. (2018). Do firms with state ownership in transitional economies take more risk? Evidence from Vietnam. Research in International Business and Finance, 46, 251-256.

World Bank (1993). The East Asian miracle: Economic growth and public policy. Retrieved from http://www.worldbank.org/curated/ en/975081468244550798/pdf/multi-page.pdf

Zhu, J., Ye, K., Tucker, J. W., \& Chan, J. K. C. (2016). Board hierarchy, independent directors, and firm value: Evidence from China. Journal of Corporate Finance, 41, 262-279. 
Zhu, W., \& Yang, J. (2016). State ownership, cross-border acquisition, and risktaking: Evidence from China's banking industry. Journal of Banking \& Finance, 71, 133-153. 